\title{
Monitoring Potential Transport of Radioactive Contaminants in Shallow Ephemeral Channels: FY 2012
}

\author{
prepared by \\ Julianne J. Miller, Steve A. Mizell, \\ Greg McCurdy, and Scott A. Campbell \\ Desert Research Institute \\ Nevada System of Higher Education \\ submitted to \\ Nevada Site Office \\ National Nuclear Security Administration \\ U.S. Department of Energy \\ Las Vegas, Nevada
}

September 2012

PUBLICATION \#45249 
Reference herein to any specific commercial product, process, or service by trade name, trademark, manufacturer, or otherwise, does not necessarily constitute or imply its endorsement, recommendation, or favoring by the United States Government or any agency thereof or its contractors or subcontractors.

Available for sale to the public from:

U.S. Department of Commerce

National Technical Information Service

5301 Shawnee Road

Alexandria, VA 22312

Phone: 800.553.6847

Fax: 703.605.6900

Email: orders@ntis.gov

Online ordering: http://www.osti.gov/ordering.htm

Available electronically at http://www.osti.gov/bridge.

Available for a processing fee to the U.S. Department of Energy and its contractors, in paper, from:

U.S. Department of Energy

Office of Scientific and Technical Information

P.O. Box 62

Oak Ridge, TN 37831-0062

Phone: 865.576.8401

Fax: 865.576.5728

Email: reports@adonis.osti.gov 


\title{
Monitoring Potential Transport of Radioactive Contaminants in Shallow Ephemeral Channels: FY 2012
}

\author{
prepared by \\ Julianne J. Miller, Steve A. Mizell, \\ Greg McCurdy, and Scott A. Campbell \\ Desert Research Institute \\ Nevada System of Higher Education
}

Publication No. 45249

submitted to

Nevada Site Office

National Nuclear Security Administration

U.S. Department of Energy

Las Vegas, Nevada

September 2012

The work upon which this report is based was supported by the U.S. Department of Energy under Contract \#DE-NA0000939. Approved for public release; further dissemination unlimited. 
THIS PAGE INTENTIONALLY LEFT BLANK 


\section{CONTENTS}

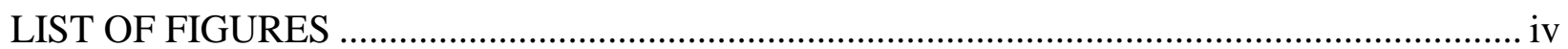

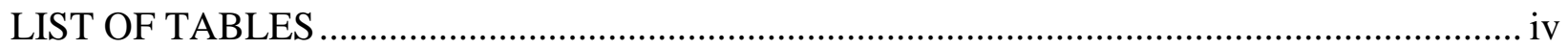

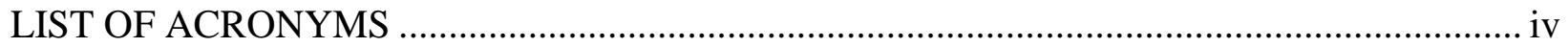

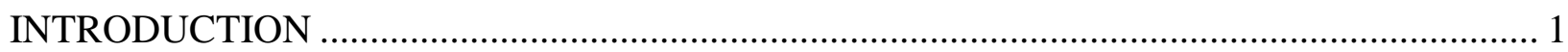

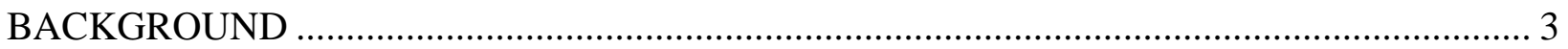

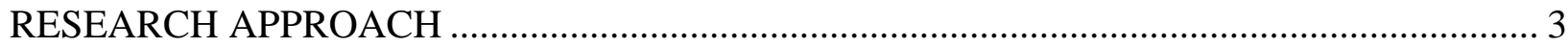

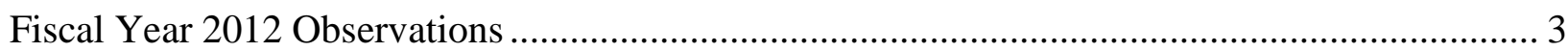

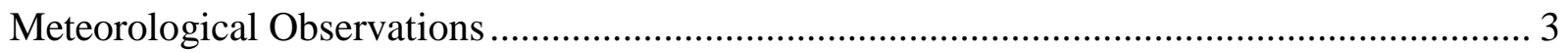

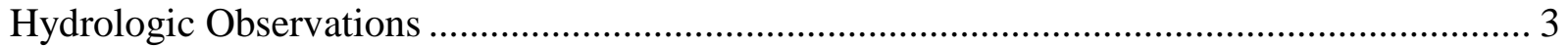

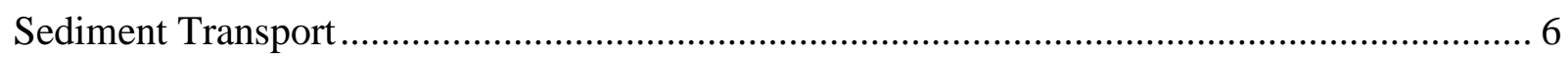

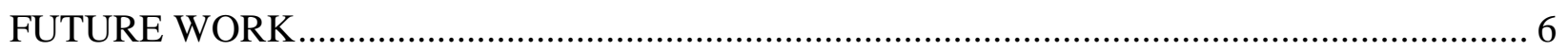

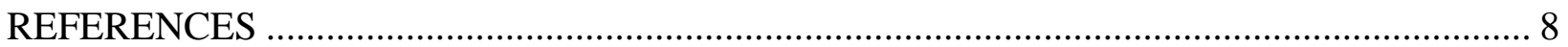

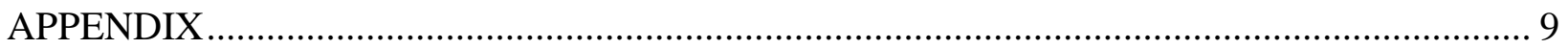




\section{LIST OF FIGURES}

1. Americium-241 detections at the Smoky CA in northwest Yucca Flat, Nevada..................... 2

2. Approximate locations of the meteorological station and flume installations at the Smoky CA in Yucca Flat, Nevada National Security Site, are shown.

3. Smoky CA meteorological station was installed to measure precipitation, wind and other climate parameters.

4. View looking downstream through the flume installed to measure runoff from the Smoky CA.

5. Runoff conditions in the flume are detected by pressure transducer, recorded in the datalogger and relayed by radio to the meteorological station for transmission to the Western Regional Climate Center via GOES satellite...

6. Changes in the white sand and painted pebble bands especially along the downstream edge will indicate sediment movement during recorded runoff events.

7. 10-minute soil moisture observations show changes that reflect precipitation events............ 5

8. 10-minute observations of the pressure transducer at the Smoky Site flume indicate water in the flume on two occasions following significant precipitation events.

9. At installation, the pebbles and sand placed in the channel above the flume at the Smoky

Site thoroughly covered the channel bed and had a nearly straight downstream edge.

\section{LIST OF TABLES}

1. Average monthly and period of record observations reflecting meteorological conditions at the Smoky Site, NNSS.

$\begin{array}{ll}\text { Am-241 } & \text { Americium-241 } \\ \text { CA } & \text { Contamination Area } \\ \text { CAS } & \text { Corrective Action Site } \\ \text { CAU } & \text { Corrective Action Unit } \\ \text { DOE } & \text { Department of Energy } \\ \text { DRI } & \text { Desert Research institute } \\ \text { GOES } & \text { Geostationary Operational Environmental Satellite } \\ \text { NNSS } & \text { Nevada National Security Site } \\ \text { NSO } & \text { Nevada Site Office } \\ \text { WRCC } & \text { Western Regional Climate Center }\end{array}$




\section{INTRODUCTION}

The US Department of Energy (DOE) National Nuclear Security Administration (NNSA), Nevada Site Office (NSO), Environmental Management's Soils Activity has authorized the Desert Research Institute (DRI) to conduct field assessments of potential sediment transport of contaminated soil from Corrective Action Unit (CAU) 550, Smoky Contamination Area (CA), during precipitation runoff events. CAU 550 includes Corrective Action Sites (CASs) 08-23-03, 08-23-04, 08-23-06, and 08-23-07; these CASs are associated with tests designated Ceres, Smoky, Oberon, and Titania, respectively.

Field measurements at the T-4 Atmospheric Test Site, CAU 370, suggest that radioactive material may have migrated along a shallow ephemeral drainage that traverses the site (NNSA/NSO, 2009). (It is not entirely clear how contaminated soils got into their present location at the T-4 Site, but flow to the channel has been redirected and the contamination does not appear to be migrating at present.) Although DRI initially looked at the CAU 370 site, given that it could not be confirmed that migration of contamination into the channel was natural, an alternate study site was selected at CAU 550. Aerial surveys in selected portions of the Nevada National Security Site (NNSS) also suggest that radioactivity may be migrating along ephemeral channels in Areas 3, 8, 11, 18, and 25 (Colton, 1999).

Figure 1 shows the results of a low-elevation aerial survey (Colton, 1999) in Area 8. The numbered markers in Figure 1 identify ground zero for three safety experiments conducted in 1958 [Oberon (number 1), Ceres (number 2), and Titania (number 4)] and a weapons effects test conducted in 1964, Mudpack (number 3). This survey suggests contaminants may be migrating down the ephemeral channels that traverse CAU 550. Note particularly the lobe of higher concentration extending southeastward at the south end of the high concentration area marked as number 3 in Figure 1.

CAU 550 in Area 8 of the NNSS was selected for the study because the aerial survey indicates that a channel mapped on the United States Geological Survey topographic map of the area traverses the south end of the area of surface contamination; this channel lies south of the point marked number 3 in Figure 1, and anecdotal information indicates that sediment has been deposited on the road bordering the southeast boundary of the CAU from an adjacent channel (Traynor, J, personal communication, 2011). Because contamination is particularly close to the boundary of CAU 550, Smoky CA, it is important to know if contaminants are moving, what meteorological conditions result in movement of contaminated soils, and what particle size fractions associated with contamination are involved.

Closure plans are being developed for the CAUs on the NNSS. The closure plans may include post-closure monitoring for possible release of radioactive contaminants. Determining the potential for transport of contaminated soils under ambient climatic conditions will facilitate an appropriate closure design and post-closure monitoring program. 

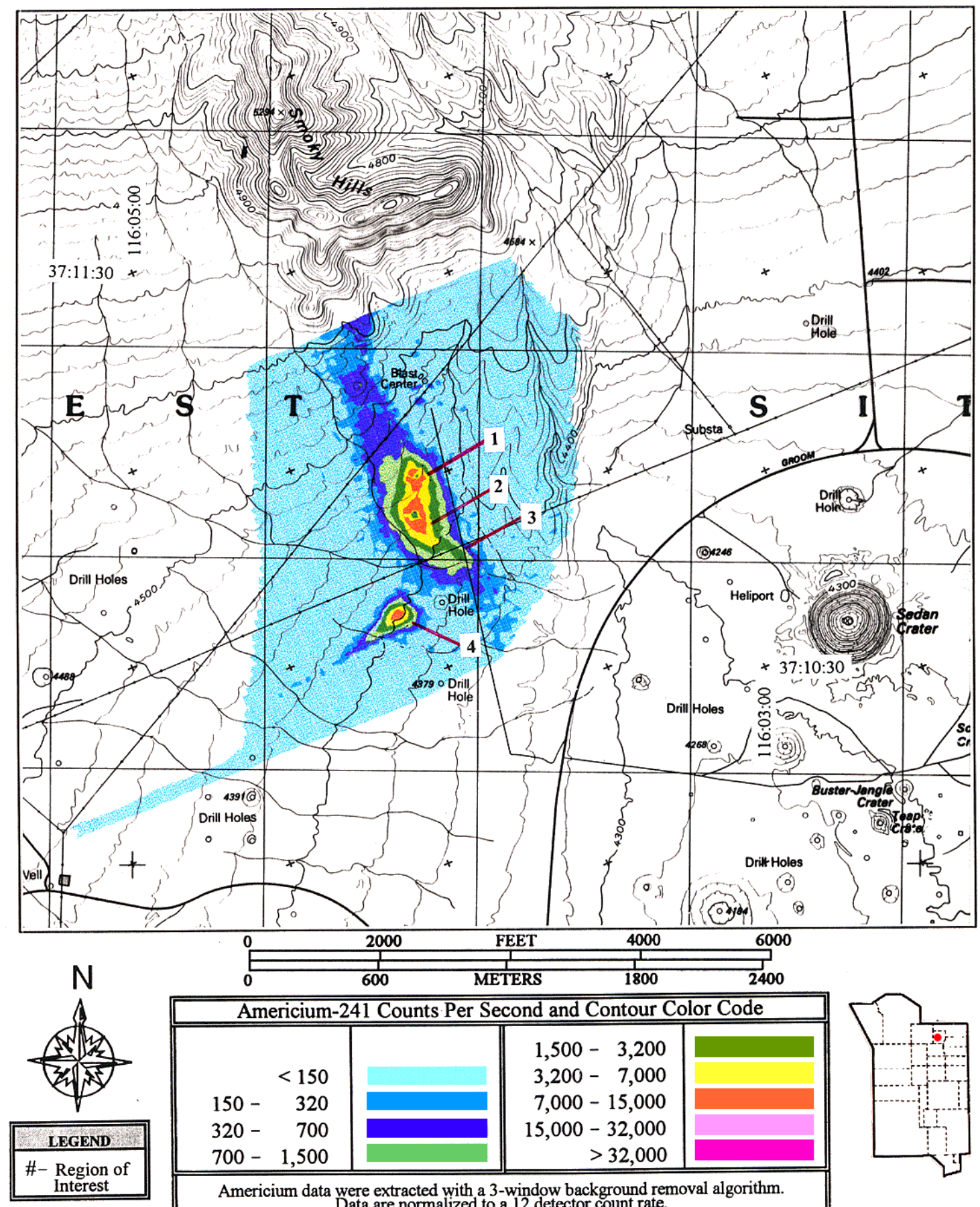

Americium data were extracted with a 3-window background removal algorithm.

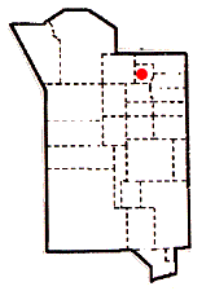
Data are normalized to a 12 detector count rate.

Figure 1. Americium-241 detections at the Smoky CA in northwest Yucca Flat, Nevada (Colton, 1999). Numbered markers identify ground zero for three safety experiments Oberon (number 1), Ceres (number 2), and Titania (number 4) and a weapons test, Mudpack (number 3). 


\section{BACKGROUND}

The Smoky CA is located in Area 8 of the NNSS in northern Yucca Flat, southeastern Nye County, Nevada. In addition to the namesake test, Smoky, an above ground nuclear device test detonated in 1957, four additional tests were conducted in the area; these include three safety tests (Oberon, Ceres, and Titania) conducted in 1958 and a weapons effect test, Mudpack, conducted in 1964 (Colton, 1999). As a result of these tests there is an elongated area of surface contamination trending in a northwest-southeast direction (Colton, 1999). This area of surface contamination encompasses the Smoky, Oberon, Ceres, and Mudpack test locations. Near the southern extent, and slightly to the southwest, of this contamination area is a triangular shaped area of surface contamination associated with the Titania test. A low-level aerial survey of the area (Figure 1) reported up to 15,000 counts per second Am-241 at the center of the two surface contamination areas (Colton, 1999). Additionally, there has been measured contamination transported across Circle Road from an adjacent channel (Traynor, J, personal communication, 2011).

The Smoky CA is situated on the alluvial fan approximately 0.3 miles $(1,000 \mathrm{~m})$ south of the Smoky Hills. Mapped drainages shown on the Oak Spring, Nevada topographic map (U.S. Geological Survey 1:24000 scale) trend south-southeast from the Smoky Hills then easterly toward the center of Yucca Flat. The larger of the two contaminated areas in the Smoky CA is bounded on the east, west and south by mapped channels. The western corner of the smaller contamination area surrounding the Titania test is drained by a mapped channel trending west to east. Elevation contours in the immediate vicinity of these contamination areas suggest unmapped channels may convey runoff from the areas of highest contamination into the mapped drainages.

\section{RESEARCH APPROACH}

The presence of radionuclide-contaminated soils in channels that traverse and convey runoff from the Smoky CA suggests that contaminated soil has been transported by rainfallrunoff. However, there is insufficient data to determine if the observed contamination is the result of an ongoing process or if the transport was limited to a period of higher hydraulic energy resulting from reduced ground cover immediately following the Smoky area tests.

Desert Research Institute proposed to perform a field scale assessment of meteorological and hydrologic conditions that would potentially lead to transport of radionuclide-contaminated soil from the Smoky CA. The research plan includes measurement of local meteorological parameters, measurement of runoff resulting from local rainfall, and visual observation of marked soil particle (tracer) migration associated with rainfall-runoff. Measurements will be made at locations in and adjacent to the Smoky CA (Figure 2). The precipitation and runoff data will be used to establish threshold conditions that would likely lead to transport of soil particles, including radionuclide-contaminated soils. Such thresholds will aid establishment of conditions that cause monitoring of drainage channel transport pathways to be implemented under a future closure plan. 


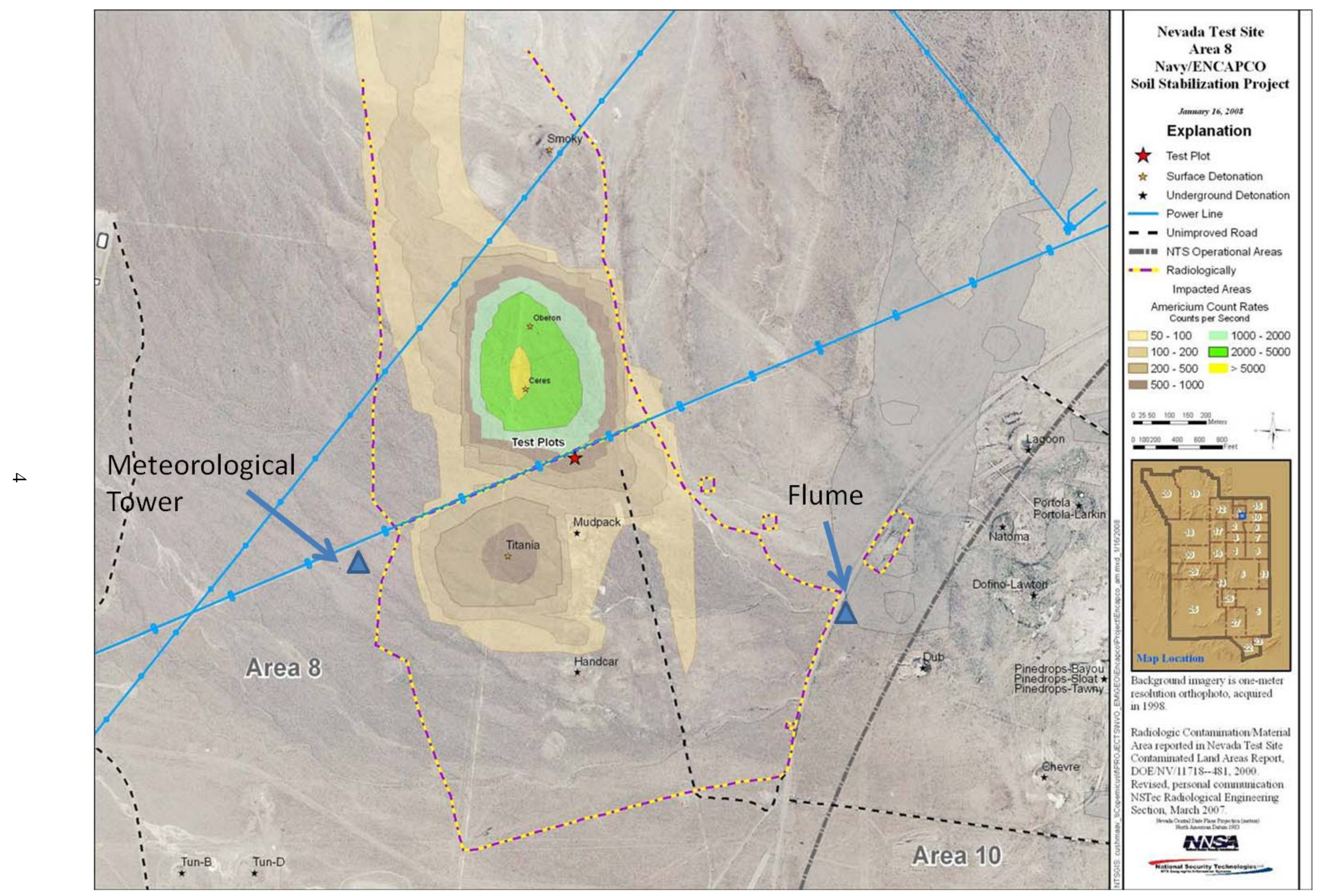

Figure 2. Approximate locations of the meteorological station and flume installations at the Smoky CA in Yucca Flat, Nevada National Security Site, are shown. 
The meteorological (met) station, including instrumentation to measure temperature, relative humidity, wind speed, wind direction, soil volumetric-water content, soil temperature, solar radiation, barometric pressure and precipitation, was installed in an uncontaminated area adjacent to the Smoky CA (Figures 2 and 3) on July 14 and 15, 2011. Coordinates of the meteorological station are $37^{\circ} 10^{\prime} 39.48$ ” latitude and $-116^{\circ} 4^{\prime} 25.59$ ” longitude. The meteorological station also includes Geostationary Operational Environmental Satellite (GOES) transmission equipment and equipment to receive radio frequency data transmissions from the flume installation (Figure 2). Accumulated meteorological data is transmitted daily to the Western Regional Climate Center (WRCC) at the DRI offices in Reno. At the WRCC the data is uploaded to a restricted access internet web page available to project personnel.

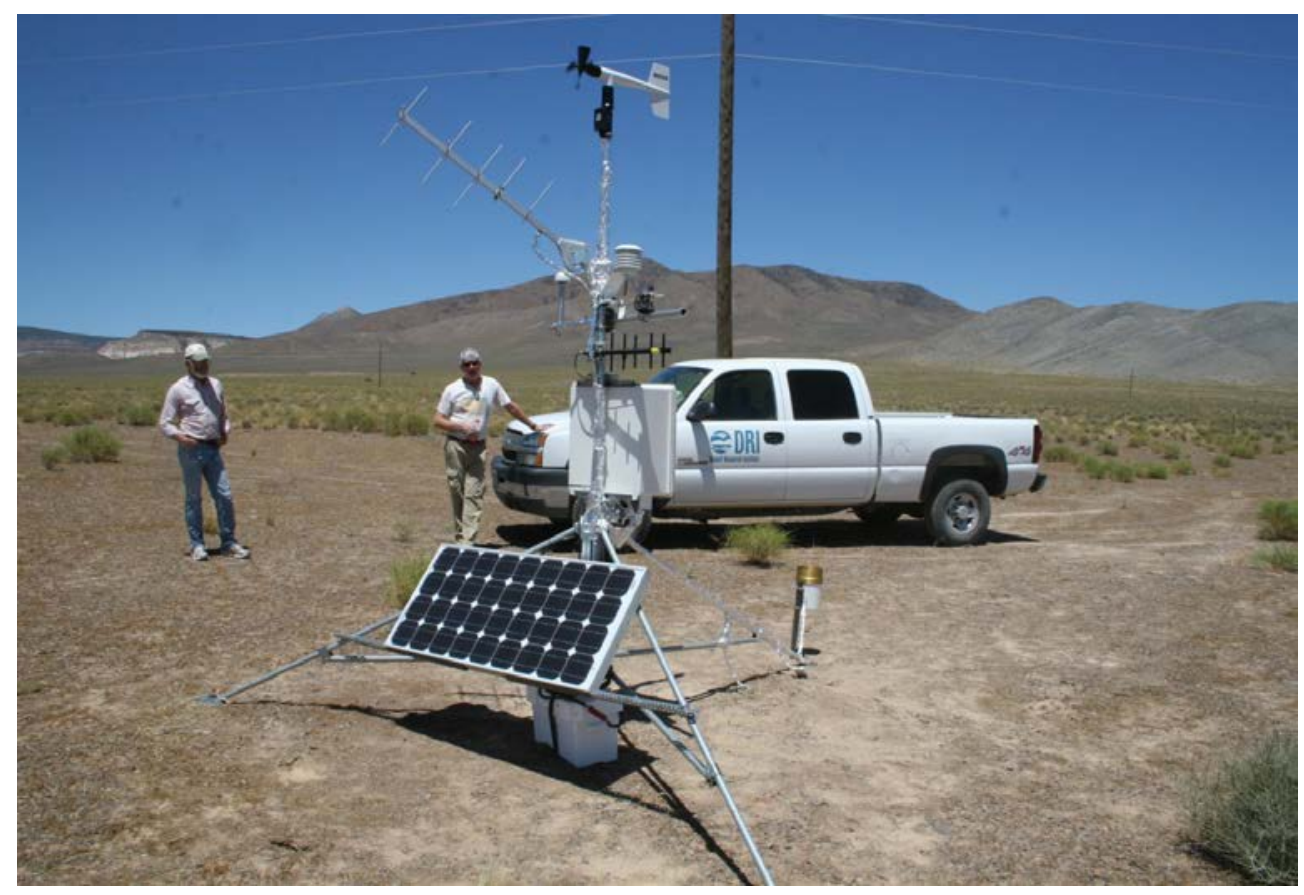

Figure 3. Smoky CA meteorological station was installed to measure precipitation, wind and other climate parameters.

A flume to measure channelized runoff was originally to be installed between the Smoky CA boundary and the adjoining road (Figure 2). However, because there was not sufficient space on the shoulder of the road and because Radiological Control determined that it was not possible to downgrade contamination controls on the study channel to be instrumented, the flume (Figures 2 and 4) was placed inside the Smoky CA. The flume was installed on July 19, 2011 at a location approximately $50 \mathrm{ft}(15 \mathrm{~m})$ upstream of the position indicated in Figure 2. Coordinates of the flume are $37^{\circ} 10^{\prime} 37.13^{\prime}$ ' latitude and $-116^{\circ} 3$ ' $34.85^{\prime}$ ' longitude. The flume installation includes a pressure transducer for measuring depth of flow through the flume and a radio frequency 
transmitter/receiver to permit communication with the met station (Figure 5). Meteorological and flume data transmissions from the Smoky CA were received beginning July 20, 2011.

White silica sand and painted river pebbles (Figure 6) were installed in the drainage channel upstream of the flume on July 19, 2011 to permit visual observation of sediment movement in the channel bed. Because it was not possible to downgrade the radiological control on the study channel, measurement of marked particle migration will be limited to times when casual observation suggests migration has occurred or entry to the CA is required to service the flume equipment.

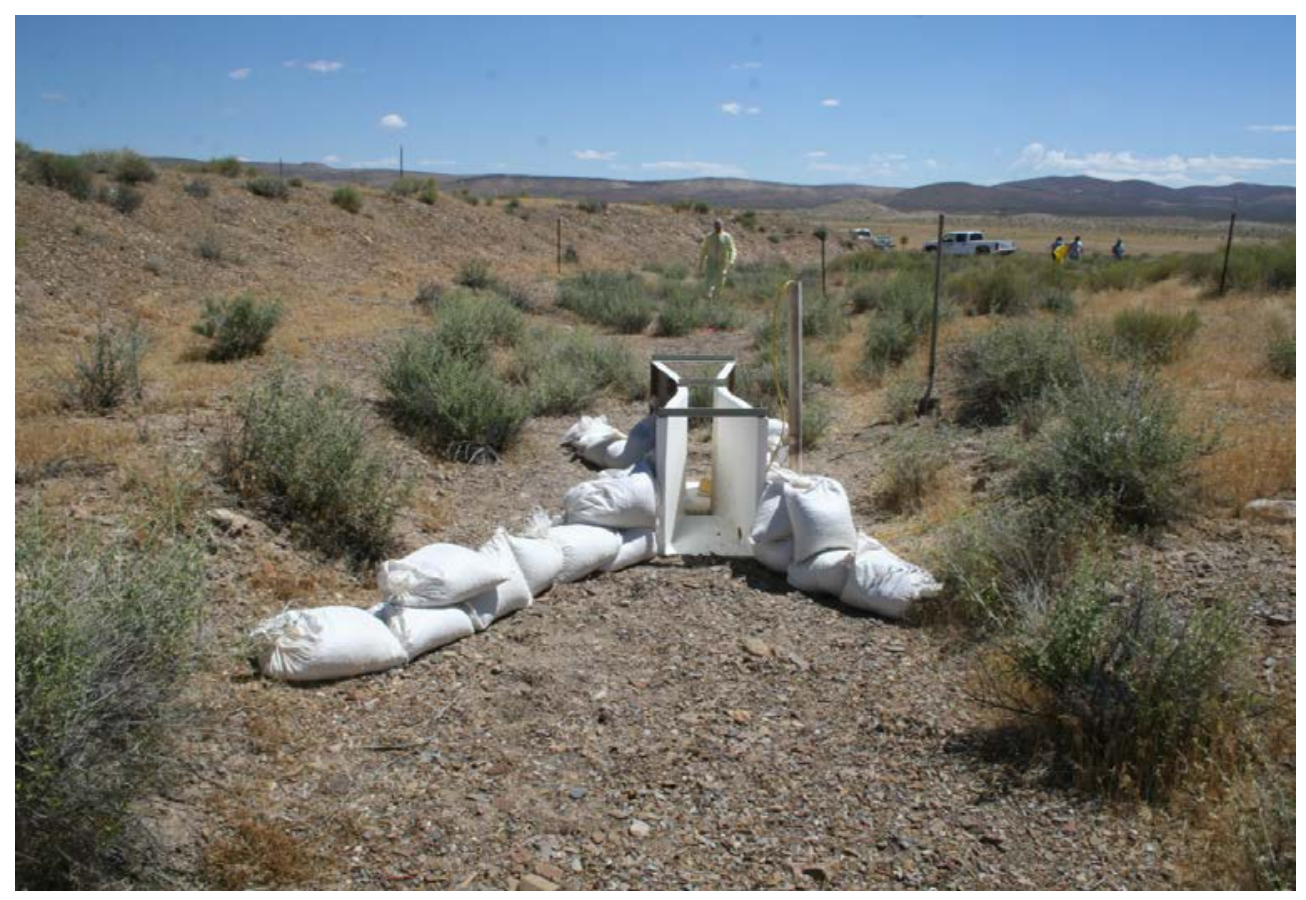

Figure 4. View looking downstream through the flume installed to measure runoff from the Smoky CA. 


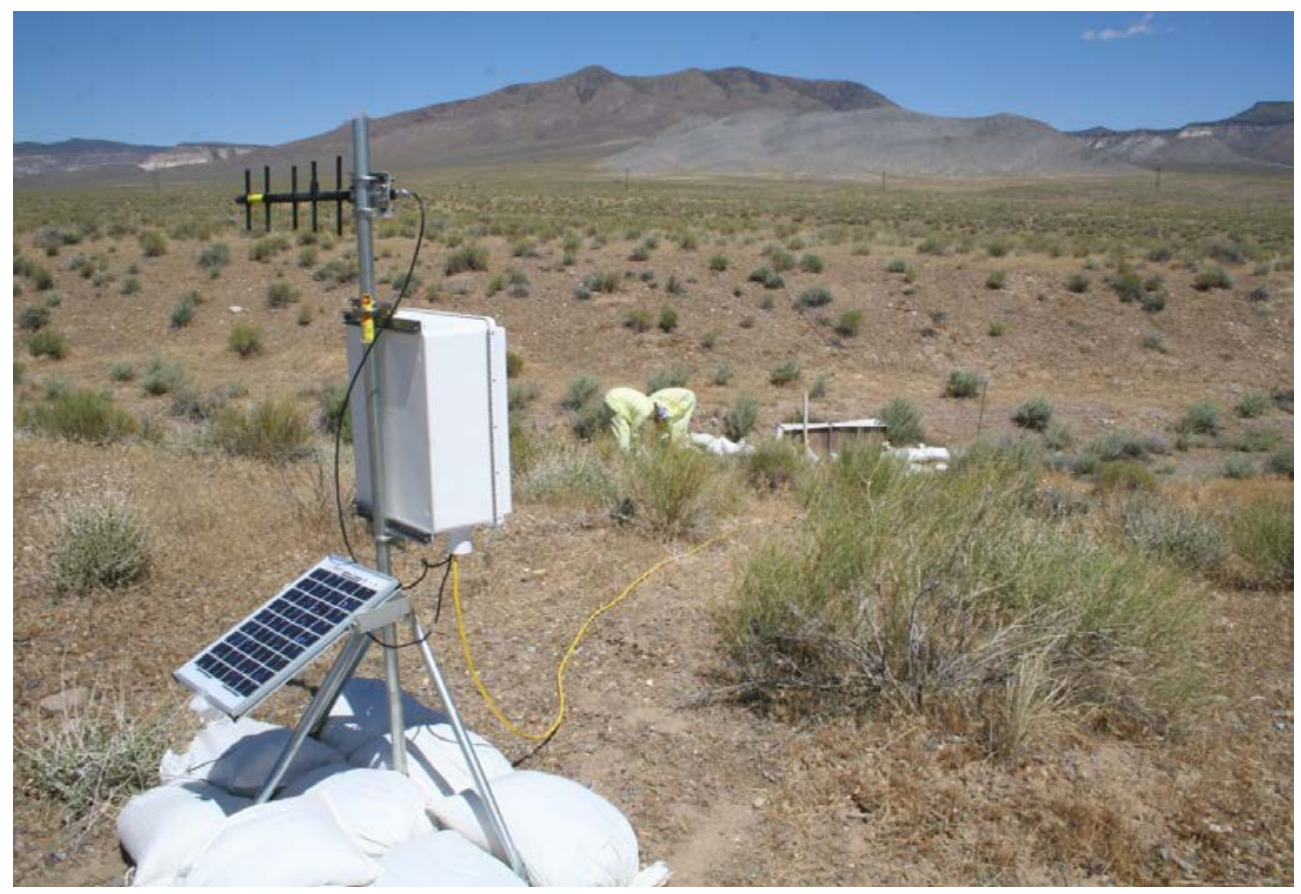

Figure 5. Runoff conditions in the flume are detected by pressure transducer (yellow cable), recorded in the datalogger (white box) and relayed by radio (black antenna) to the meteorological station for transmission to the Western Regional Climate Center via GOES satellite.

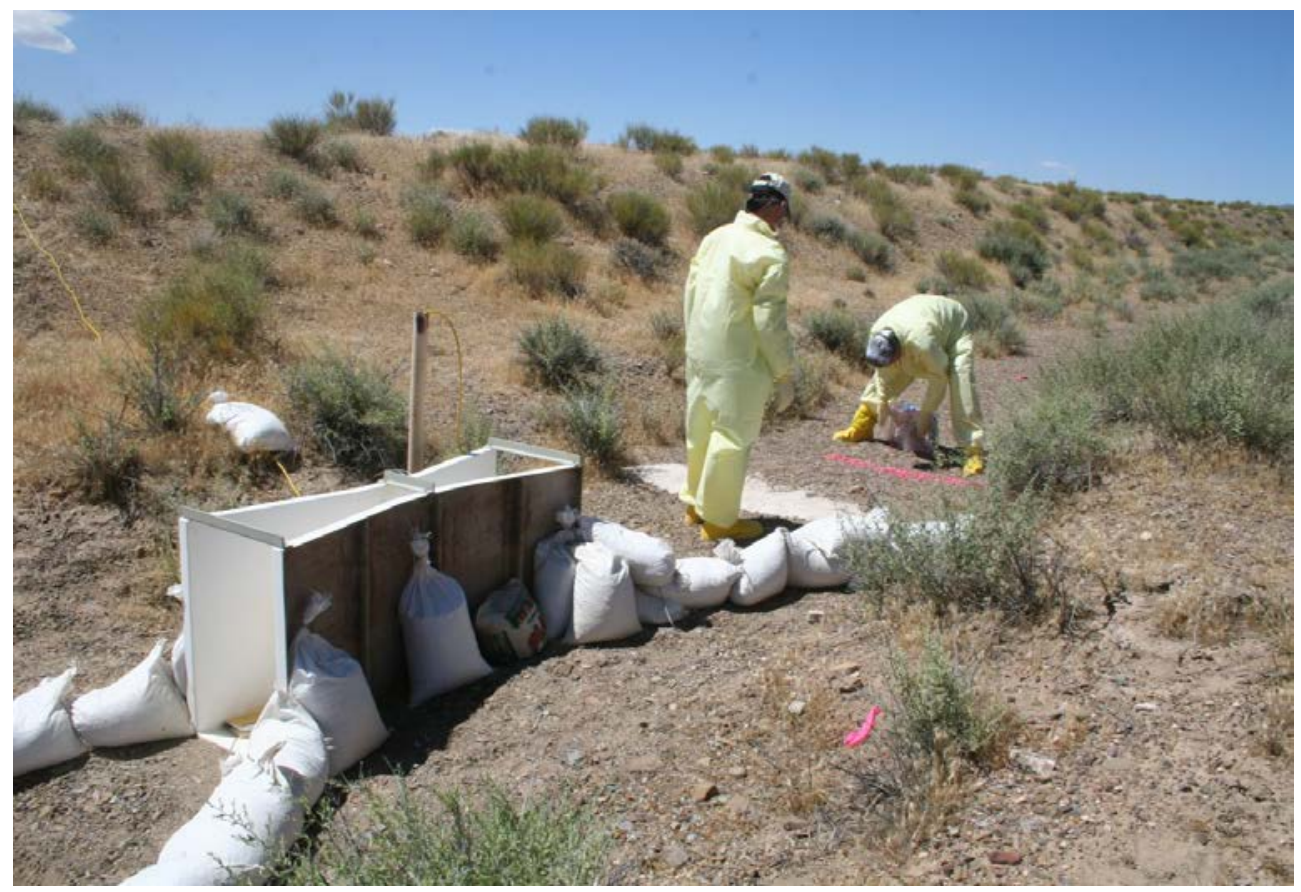

Figure 6. Changes in the white sand and painted pebble bands especially along the downstream edge will indicate sediment movement during recorded runoff events. 


\section{FISCAL YEAR 2012 OBSERVATIONS}

Measurements of air temperature, relative humidity, wind speed and direction, soil volumetric-water content, soil temperature, solar radiation, barometric pressure, precipitation, and water depth were collected every three seconds. These values were averaged or totaled, as appropriate, and recorded on the data logger every ten minutes. Because GOES transmission time is limited, the 10-minute data were averaged for each 24-hour day before transmission to the WRCC. The 10-minute data were retained on the data logger and downloaded during periodic site visits. The last datalogger download was accomplished on August 1, 2012.

\section{Meteorological Observations}

Ten-minute meteorological data through August 1 and the daily meteorological data since August 1 have been summarized by month and for the period of record in Table 1. Daily average values of the meteorological parameters are shown in time series plots presented in the Appendix. During the period of record (July 202011 through September 16 2012), the monthly summary data indicates that: (1) the average monthly temperature was warmest in July and August and coldest in December; (2) soil temperature followed a similar pattern; (3) monthly average relative humidity was highest in November 2011 and March 2012 and lowest in June 2012; (4) July and August 2012 had the highest precipitation amounts (1.19 in and 1.09 in, respectively); and the average wind speed was greatest in May 2012 and calmest in September 2011.

\section{Hydrologic Observations}

Soil moisture is measured in the top 4 inches of soil column using factory calibrated Time Domain Reflectometry (TDR) sensors installed at the meteorological station. TDR sensor readings have not been compared to laboratory determined soil moisture content and, therefore, may not reflect actual moisture content. However, they are expected to give accurate indications of changes in soil moisture content resulting from precipitation events. The observed volumetric soil moisture content ranged between 0.07 (7 \%) in early December 2011 and 0.24 (24 \%) following a significant precipitation event in mid-April 2012 (Figure 7). Generally, moisture content rose following precipitation events that exceeded 0.02 in. Rainfall of lesser magnitude did not produce a notable change in the measured moisture content. However, antecedent soil moisture conditions also played a role causing small precipitation events falling on already damp soil to produce a noticeable change in soil moisture content.

The pressure transducer depth-of-water observations at the Smoky Site flume reflect both diurnal fluctuations and a seasonal variation in a ddition to the presence and depth of water (Figure 8). The diurnal fluctuations produce the rapid changes of approximately 2 inch. These diurnal fluctuations are superimposed on the seasonal variation which is reflected in the shallow convex curve depicted by minimum values of -4 in at the beginning and end of the period of record and a peak of about -2 in in the December and January time period. Spikes in the 
Table 1. Average monthly and period of record observations reflecting meteorological conditions at the Smoky Site, NNSS.

\begin{tabular}{|c|c|c|c|c|c|c|c|c|c|c|c|c|c|c|c|c|c|}
\hline \multirow{3}{*}{$\begin{array}{c}\text { Date } \\
\text { mm-yy }\end{array}$} & \multirow{3}{*}{$\begin{array}{c}\begin{array}{c}\text { Solar } \\
\text { Radiation }\end{array} \\
\text { ly } \\
\text { Total }\end{array}$} & \multirow{3}{*}{$\begin{array}{c}\text { Mean } \\
\text { Wind } \\
\text { Speed } \\
\text { mph } \\
\text { Ave. }\end{array}$} & \multirow{3}{*}{$\begin{array}{c}\begin{array}{c}\text { Mean } \\
\text { Wind } \\
\text { Direction }\end{array} \\
\text { Deg } \\
\begin{array}{c}\text { Vector } \\
\text { Ave. }\end{array}\end{array}$} & \multirow{3}{*}{$\begin{array}{c}\begin{array}{c}\text { Maximum } \\
\text { Wind } \\
\text { Gust }\end{array} \\
\text { mph } \\
\text { Max. }\end{array}$} & \multicolumn{5}{|c|}{ Average Air Temperature } & \multirow{2}{*}{\multicolumn{3}{|c|}{$\begin{array}{l}\begin{array}{c}\text { Average Soil Temperature - } 4 \\
\text { Inches }\end{array} \\
\text { Deg F }\end{array}$}} & \multicolumn{3}{|c|}{ Average Relative Humidity } & \multirow{3}{*}{$\begin{array}{c}\begin{array}{c}\text { Barometric } \\
\text { Pressure }\end{array} \\
\text { in.Hg } \\
\text { Ave. }\end{array}$} & \multirow{3}{*}{$\begin{array}{c}\text { Precipitation } \\
\text { in } \\
\text { Total }\end{array}$} \\
\hline & & & & & \multicolumn{5}{|c|}{ Deg F } & & & & \multicolumn{3}{|c|}{$\%$} & & \\
\hline & & & & & Ave. & $\begin{array}{l}\text { Ave. } \\
\text { Daily } \\
\text { Max. }\end{array}$ & Max. & $\begin{array}{l}\text { Ave. } \\
\text { Daily } \\
\text { Min. }\end{array}$ & Min. & Ave. & Max. & Min. & Ave. & Max. & Min. & & \\
\hline Jul-11 & 11589 & 6.304 & 216.2 & 37.7 & 79.08 & 91.61 & 96.13 & 63.25 & 54.81 & 88.34 & 115.9 & 65.59 & 23.99 & 97.5 & 2.751 & 25.52 & 0.3 \\
\hline Aug-11 & 19982 & 5.888 & 226.3 & 36.09 & 80.32 & 94.26 & 99.14 & 63.33 & 56.23 & 89.35 & 116.2 & 65.59 & 18.71 & 100 & 1.182 & 25.54 & 0.08 \\
\hline Sep-11 & 15223 & 4.673 & 307.3 & 38.29 & 72.93 & 86.98 & 93.65 & 57.33 & 52.11 & 80.23 & 109.3 & 60.39 & 25.45 & 96.8 & 2.802 & 25.6 & 0.24 \\
\hline Oct-11 & 13663 & 5.528 & 304.3 & 38.73 & 59.95 & 74.53 & 85.89 & 44.24 & 29.42 & 66.28 & 95.32 & 40.05 & 26.97 & 96.6 & 3.965 & 25.59 & 0.03 \\
\hline Nov-11 & 8891 & 4.788 & 309.6 & 48.66 & 42.93 & 56.09 & 69.69 & 30.17 & 19.71 & 47.06 & 71.56 & 29.55 & 40.37 & 94.3 & 6.337 & 25.59 & 0 \\
\hline Dec-11 & 8245 & 6.277 & 336.8 & 52.17 & 38.24 & 51.76 & 65.07 & 25.17 & 14.2 & 39.1 & 59.76 & 22.7 & 35.21 & 99.8 & 5.478 & 25.66 & 0.12 \\
\hline Jan-12 & 9402 & 4.846 & 313.1 & 37.63 & 41.37 & 56.23 & 69.46 & 27.17 & 12.42 & 41.83 & 64.69 & 21.24 & 29.97 & 98.7 & 3.966 & 25.67 & 0.11 \\
\hline Feb-12 & 10978 & 6.022 & 323.1 & 46.18 & 42.14 & 53.85 & 67.89 & 29.81 & 20.04 & 46.16 & 71.56 & 27.28 & 40.03 & 100 & 0.915 & 25.55 & 0.34 \\
\hline Mar-12 & 15195 & 7.219 & 222.7 & 49.69 & 48.56 & 61.54 & 74.17 & 34.21 & 22.4 & 53.68 & 83.73 & 30.7 & 34.37 & 96.9 & 4.59 & 25.49 & 0.16 \\
\hline Apr-12 & 18549 & 6.994 & 263.6 & 39.75 & 57.69 & 69.71 & 87.89 & 43.91 & 28.84 & 65.27 & 101.5 & 36.62 & 28.21 & 100 & 0.002 & 25.5 & 0.76 \\
\hline May-12 & 23315 & 8.271 & 289.2 & 45.52 & 69.05 & 81 & 93.79 & 53.80 & 36.07 & 79.77 & 114.9 & 49.73 & 14.43 & 73.96 & 0.864 & 25.46 & 0 \\
\hline Jun-12 & 24120 & 7.709 & 218.2 & 40.04 & 76.68 & 89.75 & 96.57 & 59.23 & 47.10 & 88.11 & 120.1 & 57.94 & 10.92 & 43.97 & 1.234 & 25.46 & 0 \\
\hline Jul-12 & 21129 & 5.669 & 203.6 & 33.98 & 79.85 & 92.49 & 104.6 & 64.2 & 55.81 & 89.98 & 124.3 & 64.02 & 27.74 & 97.6 & 1.37 & 25.56 & 1.19 \\
\hline Aug-12 & 18472 & 5.374 & 211.8 & 42.82 & 81.39 & 93.11 & 100.9 & 68.74 & 61.47 & 89.51 & 116.6 & 66.07 & 35.44 & 95.7 & 7.967 & 25.57 & 1.09 \\
\hline Sep-12 & 8967 & 4.936 & 265.8 & 31.78 & 75.62 & 87.17 & 93.15 & 62.55 & 55.58 & 82.66 & 106.8 & 62.35 & 27.81 & 86.5 & 2.732 & 25.63 & 0.24 \\
\hline $\begin{array}{l}\text { Record } \\
\text { Average }\end{array}$ & 15181 & 6.03 & 267.4 & 41.3 & 63.05 & 76.01 & 86.53 & 48.47 & 37.75 & 69.82 & 98.15 & 46.65 & 27.97 & 91.89 & 3.08 & 25.56 & 0.31 \\
\hline
\end{tabular}




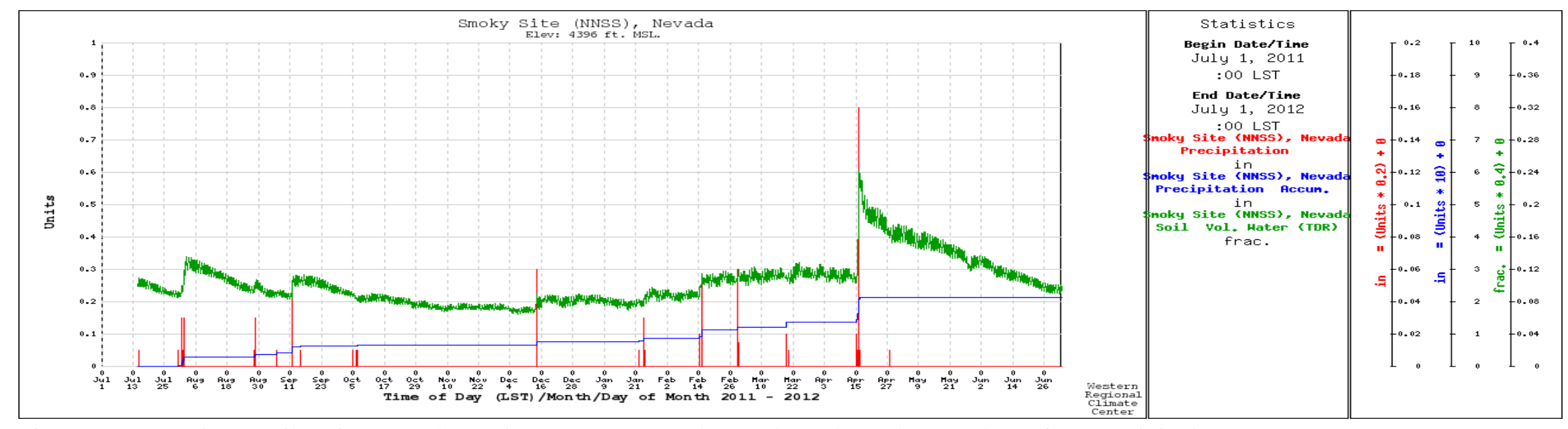

Figure 7. 10-minute soil moisture (volumetric water content) observations show changes that reflect precipitation events.

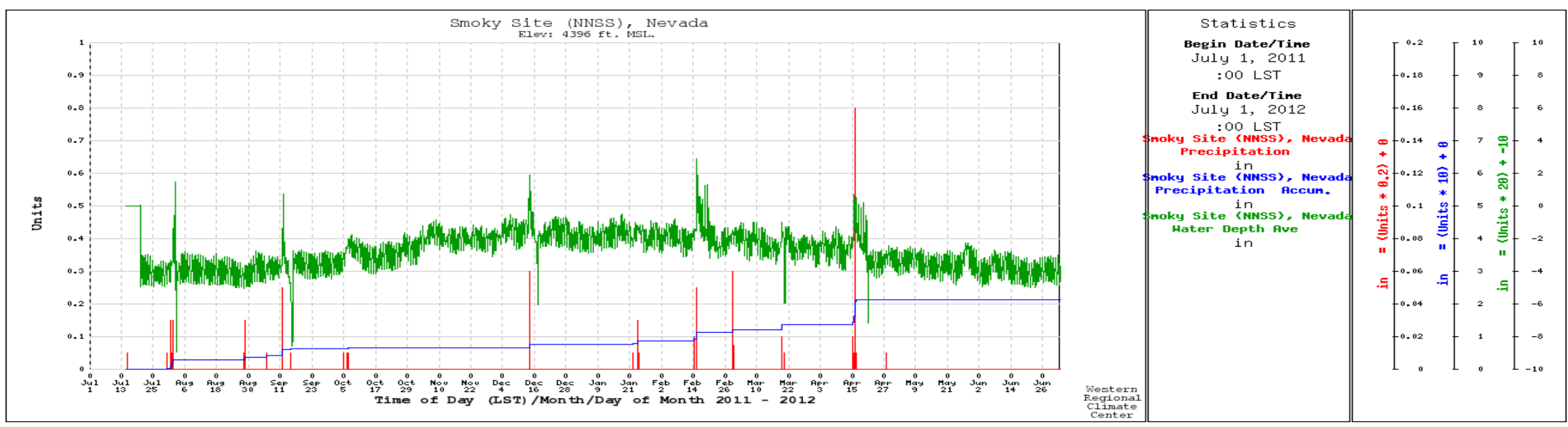

Figure 8. 10-minute observations of the pressure transducer at the Smoky Site flume indicate water in the flume on two occasions following significant precipitation events. 
transducer record may reflect the presence of water in the flume as a result of runoff events. The seasonal curve may be removed by subtracting from the observed value an amount that caused the non-runoff values to be -4 in across the entire period of record. If this approach is used to adjust all of the transducer data, then the spikes of Sep 11, Dec 16, and Apr 15 are reduced to values of less than 0.0. The spike in early August represents about 1.5 in of water and the spike in mid-February represents about 1 in of water. The 1.5 in of water indicated in August followed a 0.03 in precipitation event that lasted approximately 30 minutes and the 1.0 in of water indicated in February followed a precipitation event of approximately 0.05 in. After adjustment the other peaks in the pressure transducer depth-of-water record did not exceed 0.0 in of water despite notable precipitation. For example, a mid-April precipitation event of approximately 0.16 in produced a spike in the depth-of-water data that after adjustment for the seasonal variation did not exceed 0.0 in of water. The flume is located $1,257 \mathrm{~m}$ ( 0.75 miles) east of, and about $120 \mathrm{ft}$ lower than, the meteorological station. This separation distance could be sufficient to produce different precipitation amounts during individual storm events.

\section{Sediment Transport}

The Smoky Site was visited 30 July 2012 to confirm operation of communications equipment and to assess conditions at the flume installation. During the site visit, it was noted that the sand placed in the channel showed effect of water flow. The painted pebbles were not useful as tracers of runoff transport because the paint was no longer visible on most pebbles. The sand displayed a much more irregular edge on the downstream side than when installed and native gravel was scattered over the top of the remaining sand (Figure 9). Both of these observations indicate that water flowed over this area during one or more of the precipitation events of the past year.

\section{FUTURE WORK}

Data transmitted from the Smoky CA instrumentation will be reviewed monthly by project personnel to identify precipitation events that exceed the specified rainfall threshold $(\sim 0.2$ inches $[0.5 \mathrm{~cm}])$ and to assess proper operation of the instrumentation and remote communication equipment. Field inspections will be scheduled to service instrumentation if necessary.

Meteorological data collected leading up to and during a detected runoff event will be analyzed to characterize the meteorological conditions that produced the runoff. This analysis will help delineate threshold conditions that are likely to result in sediment transport and migration of radionuclides in conjunction with the sediment. Establishment of these thresholds will aid identification of meteorological conditions that may require monitoring and sampling of channel runoff migration pathways under a closure plan. Requirements for monitoring meteorological conditions and for sampling runoff pathways can then be appropriately incorporated in closure plans. 


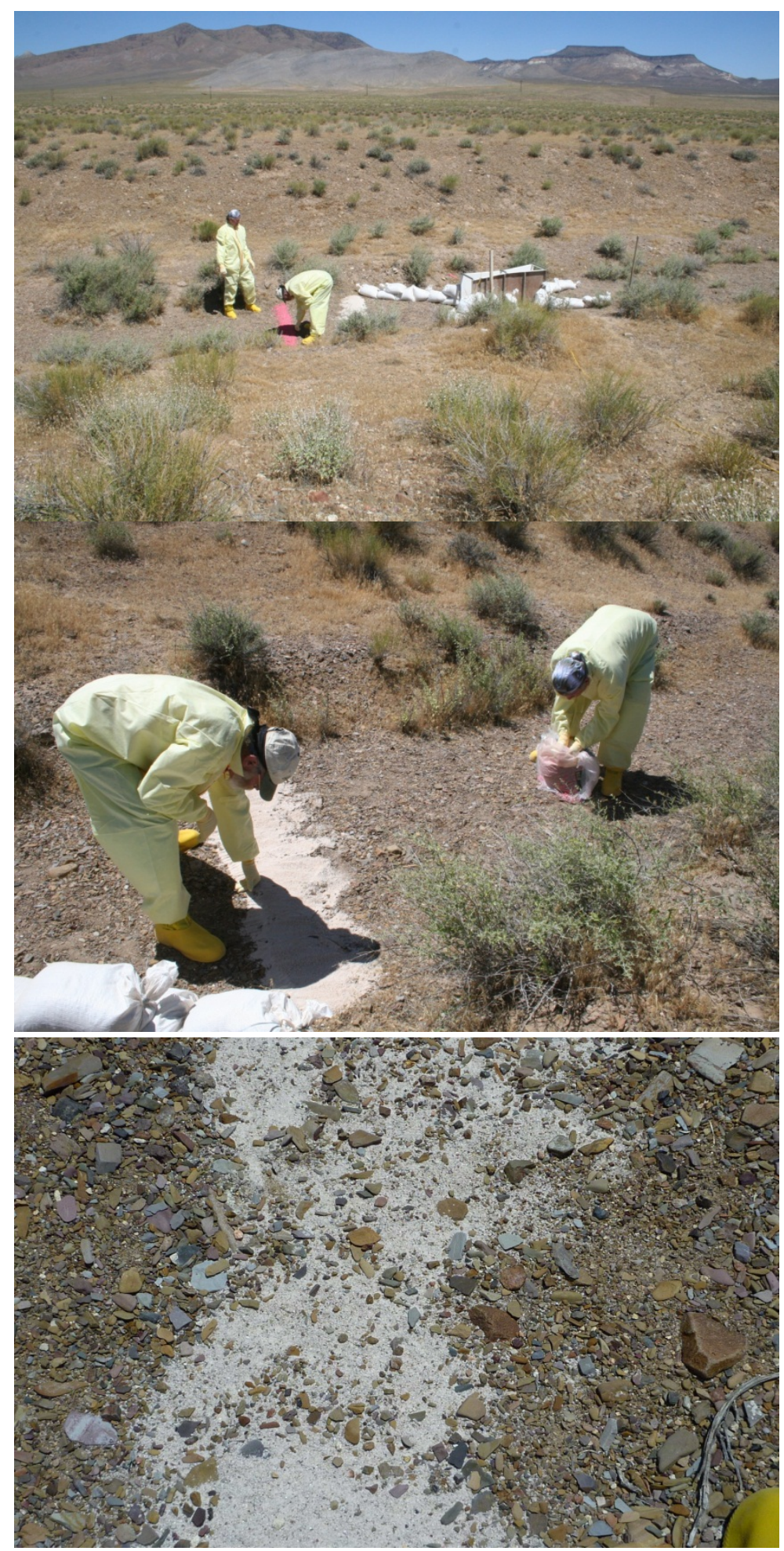

Figure 9. At installation, the pebbles (pea gravel) and sand placed in the channel above the flume at the Smoky Site thoroughly covered the channel bed and had a nearly straight downstream edge (top two images). The lower photo, taken July 2012, shows irregularity in the downstream edge of the sand and native gravel on top of the sand. 
During site visits to service instrumentation, the migration of marked soil particles will be noted to generate a qualitative response of soil migration in response to accumulated rainfallrunoff events. Bedload samples will be collected downstream of the flume following measurable rainfall-runoff events to determine the size of soil material moved and the concentration of radionuclides, if any, associated with the migrating sediment.

Because they are located inside the CA, any service work on the flume or data logger and communication equipment associated with the flume will require Radiological Control Technician support.

\section{REFERENCES}

Colton, D. 1999. A series of low-altitude aerial radiological surveys of selected regions within areas 3, 5, 8, 9, 11, 18, and 25 at the Nevada Test Site. DOE/NV/11718-362, prepared for the U.S. Department of Energy, Nevada Operations Office by Bechtel Nevada.

Traynor, J,personal communication, 2011

NNSA/NSO. 2009. Corrective Action Decision Document/Closure Report for CAU 370: T-4 Atmospheric Test Site, Nevada Test Site, Nevada, Rev. 0, May 2009 
APPENDIX - Period of Record Charts of Meteorological Observations

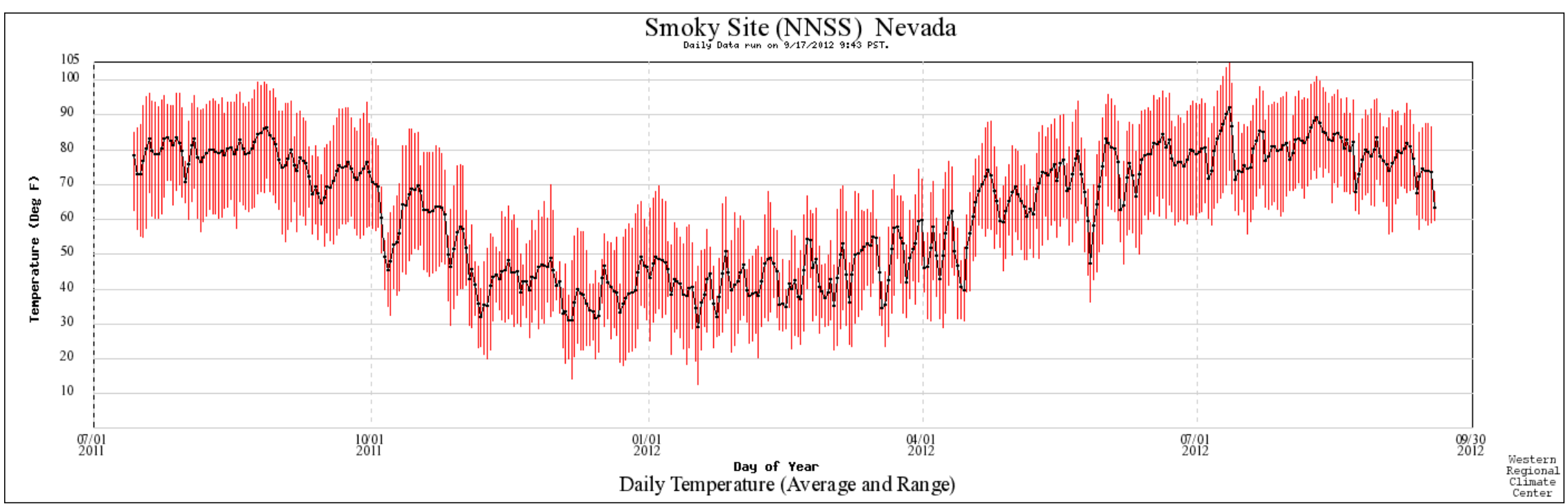




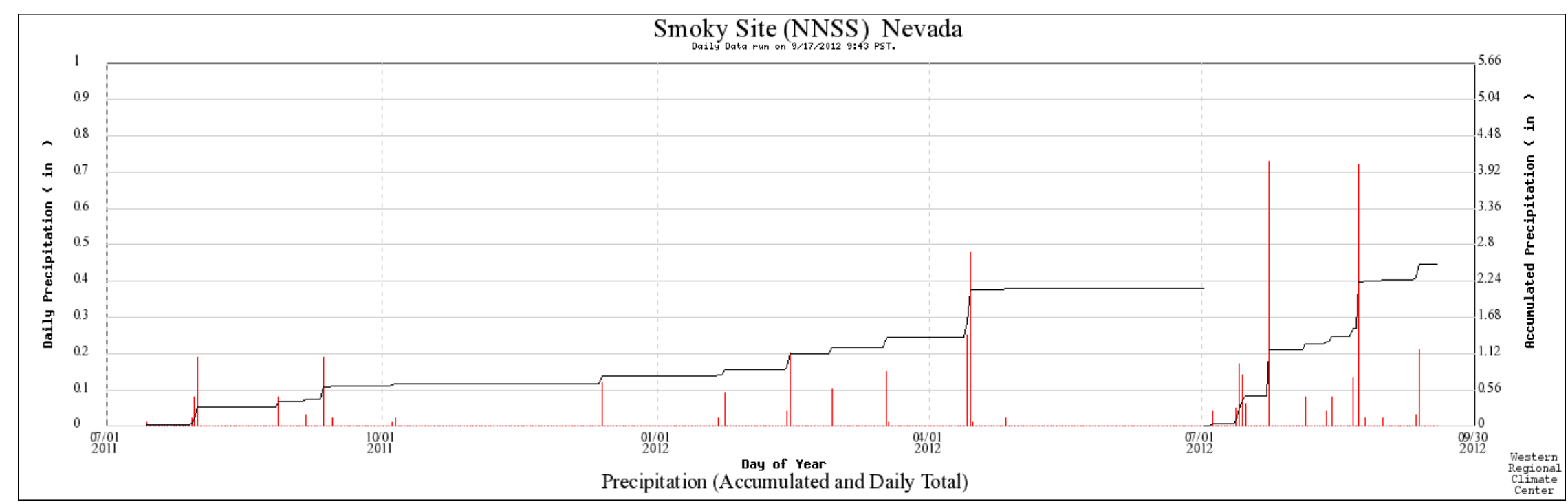

Figure A2. Precipitation exceeded 0.01 inches on eleven days during the period of record resulting in an accumulation of approximately 2.24 inches during the first 12 months of data collection and 4.7 in for the entire period of record illustrated. 


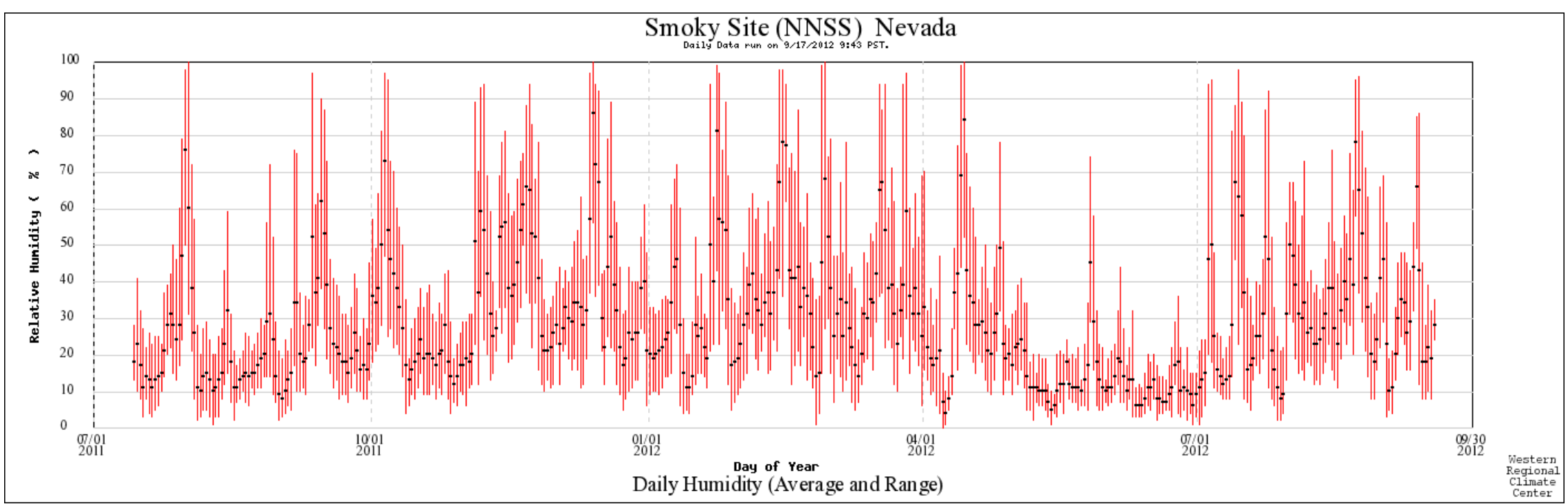

Figure A3. The relative humidity exceeded $80 \%$ on numerous occasions during the period of record. The period of high humidity in December 2011 is not associated with a precipitation event. 


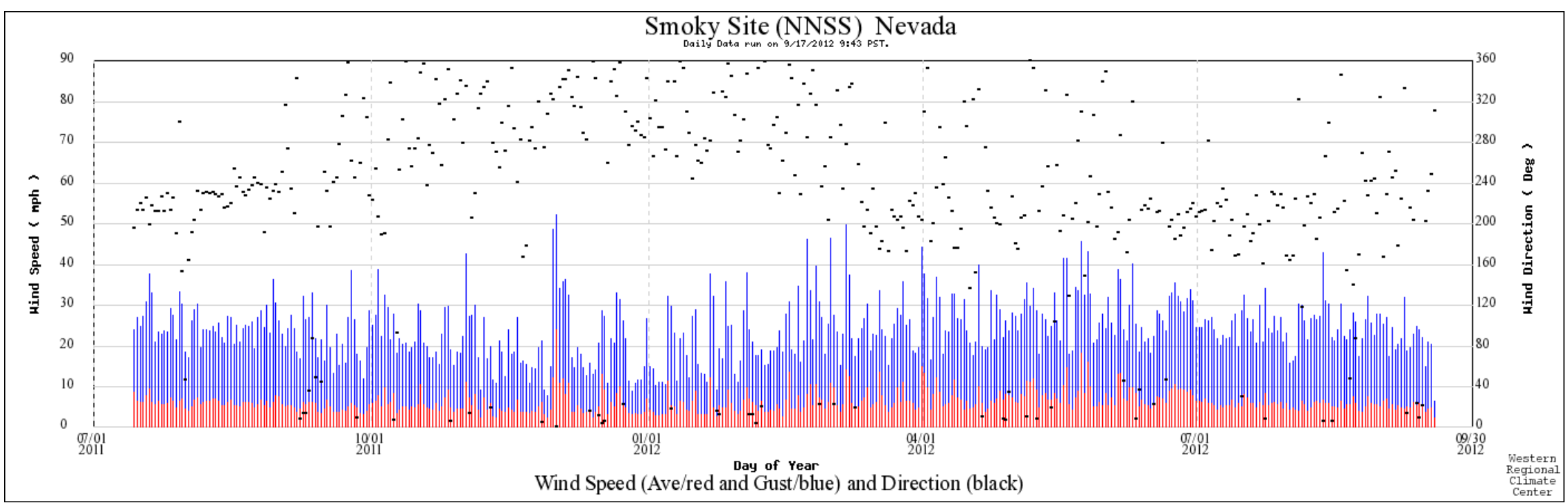

Figure A4. The peak wind velocity exceeded $50 \mathrm{mph}$. Wind direction tended to be from the southwest between April and September and northwesterly between October and March. 


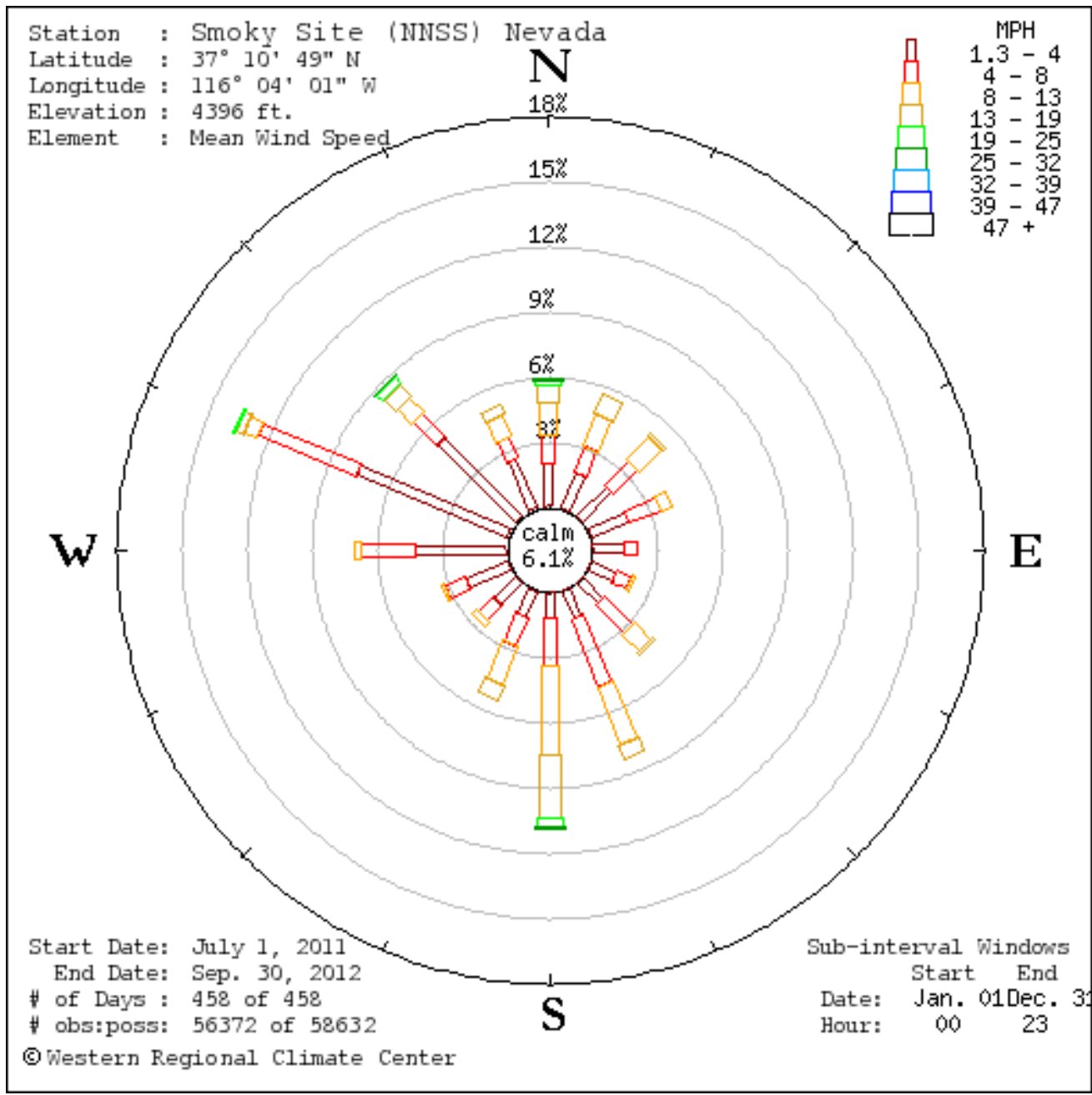

Figure A5. The wind rose shows stronger winds tend to come from the north, northwest, and south. Winds from the northwest and south are predominant. 


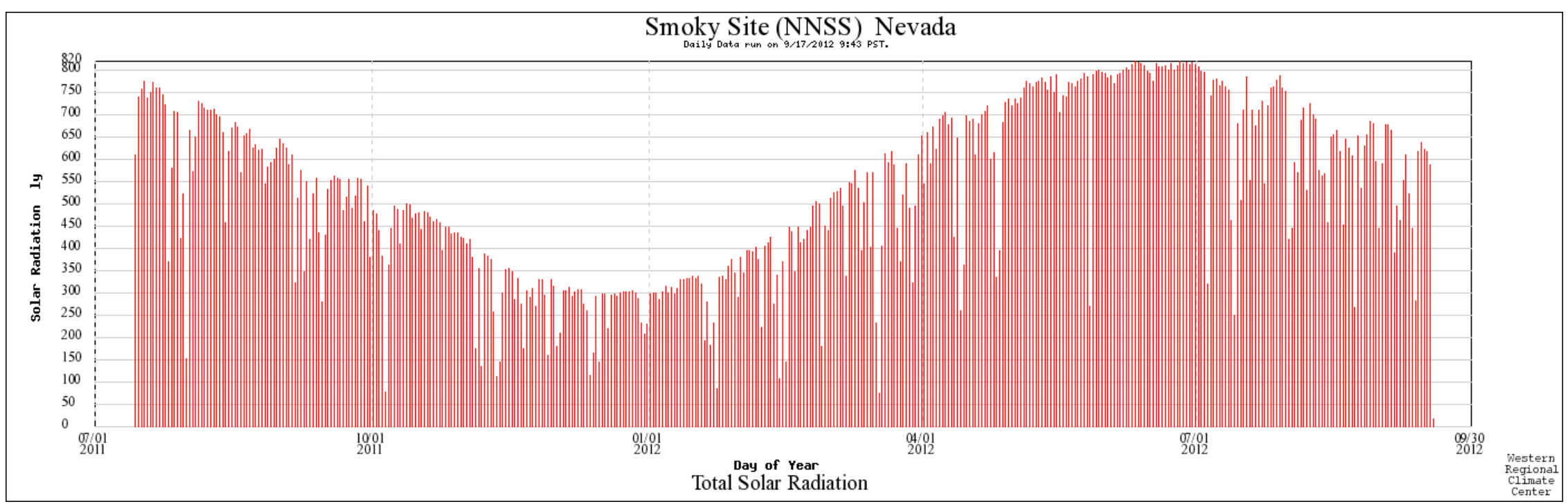

Figure A6. Solar radiation was greatest in the summer and lowest in the late fall and winter. 


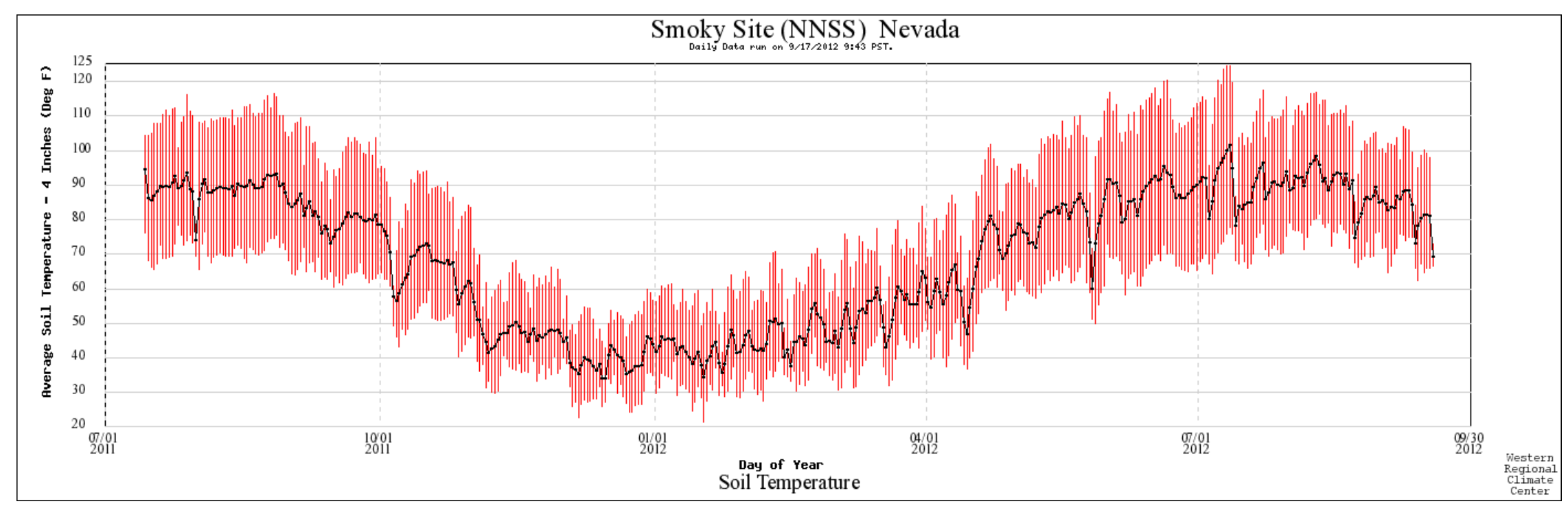

Figure A7. Soil temperature reflects a seasonal pattern similar to air temperature. 


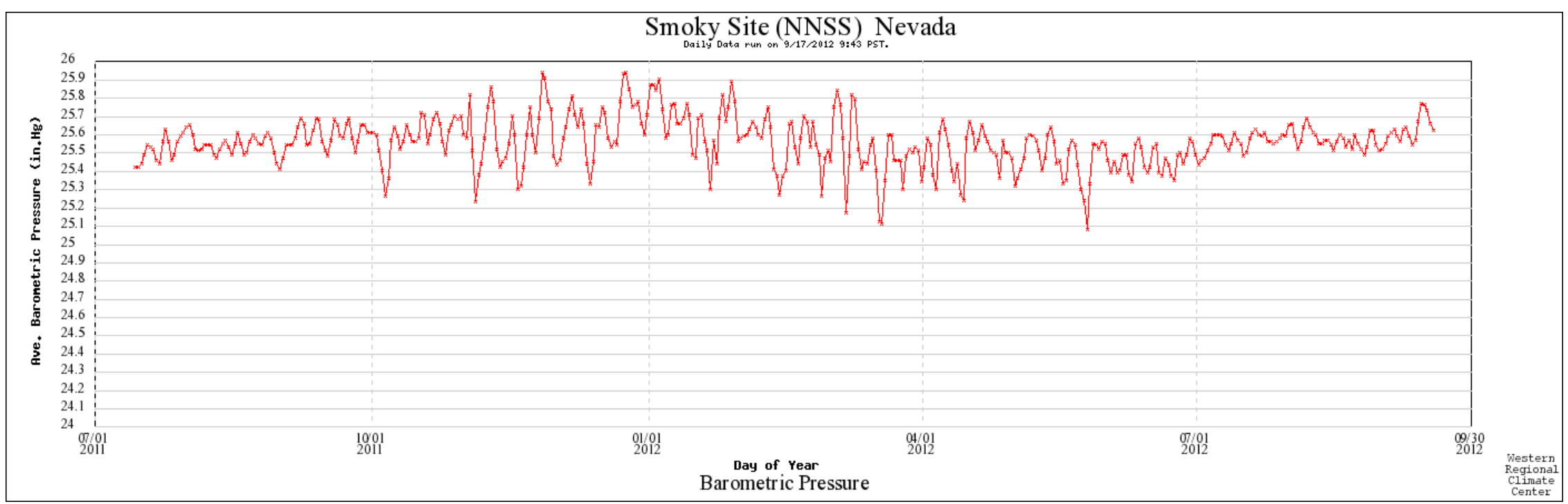

Figure A8. Barometric pressure during the period of record fluctuated between 25.2 and 25.9 inches of mercury. 